\title{
Chronobiology and obesity
}

\author{
Marta Garaulet and Purificación Gómez-Abellán \\ Department of Physiology. School of Biology. University of Murcia. Murcia. Spain.
}

\begin{abstract}
Chronobiology is a word derived from three Greek stems: kronos for time, bios for life and $\log o$ s for study. From microarrays studies, now it is accepted that $10-30 \%$ of the human genome is under the control of circadian molecular clocks. This implies that most behavioral, physiological and biochemical variables display circadian rhythms in their expression. In its simplest form, circadian clocks are composed of a set of proteins that generate selfsustained circadian oscillations. The molecular clock comprises two transcription factors, CLOCK and BMAL1, whereas PERs and CRYs are responsible for the negative limb. One of the most important questions related to the circadian system and obesity, was to elucidate if adipose tissue displayed circadian rhythmicity or whether it had an internal peripheral clock. Our group of research has provided an overall view of the internal temporal order of circadian rhythms in human adipose tissue.

A new concept related to illness is Chronodisruption (CD). It is defined as a relevant disturbance of the internal temporal order of physiological and behavioral circadian rhythms. In our modern society, CD may be common in several conditions such as jet lag, shift work, light at night, or social jet lag. In addition clock gene polymorphisms and aging may have also chronodisruptive effects. Our group has also demonstrated that Obesity and CD are also highly interconnected. With the help of chronobiology we can reach a new view of obesity considering not only "what" are the factors involved in obesity, but also "when" these factors are produced.
\end{abstract}

Nutr Hosp 2013; 28 (Supl. 5):114-120

Key words: Chronobiology. Obesity. Chronodisruption. Epigenetics. Human adipose tissue.

\section{CRONOBIOLOGÍA Y OBESIDAD}

\section{Resumen}

Cronobiología es una palabra de origen griego: kronos significa tiempo, bios, vida y logos, estudio. A partir de los estudios de microarrays, se acepta en la actualidad que del 10 al $30 \%$ del genoma humano queda bajo el control de relojes moleculares circadianos. Este implica que la expresión de la mayor parte de las variables de la conducta, psicológicas y bioquímicas muestran ritmos circadianos. En su forma más sencilla, los relojes circadianos están compuestos por un conjunto de proteínas que generan oscilaciones circadianas auto-mantenidas. EI reloj molecular comprende dos factores de trascripción, CLOCK y BMAL1, mientras que los PERs y los CRYs son responsables de la fracción negativa. Una de las preguntas más importantes relacionadas con el sistema circadiano y la obesidad fue dilucidar si el tejido adiposo mostraba un ritmo circadiano o si poseía un reloj periférico interno. Nuestro grupo de investigación proporcionó una visión de conjunto del orden temporal interno de los ritmos circadianos del tejido adiposo humano.

Un nuevo concepto relacionado con la enfermedad es el de cronodisrupción (CD). Se define como una alteración relevante del orden temporal interno de los ritmos circadianos fisiológicos y conductuales. En nuestra sociedad moderna, la CD podría ser frecuente en diversos trastornos como el jet lag, el trabajo a turnos, la luz nocturna o el jet lag social. Además, los polimorfismos de los genes horarios y el envejecimiento también podrían tener efectos de cronodisrupción. Nuestro grupo también ha demostrado que la obesidad y la CD están muy interconectadas. Con la ayuda de la cronobiología podemos llegar a un nuevo enfoque de la obesidad, considerando no solamente "cuáles" son los factores implicados en la obesidad, sino también "cuándo" se producen estos factores.

Nutr Hosp 2013; 28 (Supl. 5):114-120

Palabras clave: Cronobiología. Obesidad. Cronodisrupción. Epigenética. Tejido adiposo humano. 


\section{Abbreviations}

AT: adipose tissue.

BMI: body mass index.

$L E P$ : leptin.

LEPR: leptin receptor.

$\mathrm{V}$ : visceral.

S: subcutaneous.

MetS: Metabolic Syndrome.

SCN: suprachiasmatic nucleus.

CLOCK: circadian locomotor output cycles kaput).

$B M A L 1$ : brain- and muscle- ANRT-like protein.

PER: period.

$C R Y$ : cryptocrome.

$R E V$-ERB $\alpha$ : reverse erythroblastosis virus $\alpha$.

$R O R \alpha$ : retinoic acid receptor-related orphan receptor $\alpha$.

$A D I P O Q$ : adiponectin.

RHT: retino-hypothalamic tract.

CCG: clock-controlled genes.

CD: Chronodisruption.

\section{Introduction}

Chronobiology is a word derived from three Greek stems: kronos for time, bios for life and logos for study, which is a relatively new science which was first discovered in the eighteenth century. It came out with Linnaeus, who designed a beautiful "floral clock" that represented the hours of the day depending on the time that flowers open their petals. ${ }^{1}$ It is a scientific field which studies the timing processes (the biological rhythms) which occur in the living organisms at their different levels of organization. Circadian rhythms are those biological rhythms whose frequency is close to a day (period between $>20$ and $<28 \mathrm{~h}$ ) such as the rhythms of secretion of some hormones (cortisol, melatonin, etc.). Ultradian rhythms refer to those rhythms whose frequency is higher than one cycle per day (period less than $20 \mathrm{~h}$ ) such as breathing, heart beats, intestinal movements, etc. while, infradian rhythms are those whose frequency is lower than one cycle per day (period more than $28 \mathrm{~h}$ ) such as the circalunar rhythms or the menstrual cycle in humans. All these types or rhythms characterize the biological function in different animal species including humans.

Circadian control of glucose metabolism has also been recognized from studies demonstrating variation in glucose tolerance and insulin action across the day. In humans, it has been repeatedly shown that glucose tolerance is impaired in the afternoon and evening compared with the morning hours. This situation has been ascribed to the impaired insulin sensitivity of the peripheral tissues and to a relative decrease in insulin secretion during the evening hours. ${ }^{2}$

\section{How molecular clocks coordinate metabolism}

From microarrays studies, now it is accepted that 10$30 \%$ of the human genome is under the control of circadian molecular clocks. ${ }^{3}$ This implies that most behavioral, physiological and biochemical variables display circadian rhythms in their expression. The rhythms of cortisol, growth hormone, leptin, and melatonin are some examples. ${ }^{4}$ However, together with the existence of circadian rhythmicity it has been demonstrated the importance of the maintenance of an adequate internal temporal order between different variables. According to this, the peaks and troughs of every variable have to be finely tuned by the circadian system to keep a health status as occurred in a music orchestra when plays a classical music. As occurred in a symphony orchestra, the circadian orchestra is hierarchically organized, being its conductor, the suprachiasmatic nucleus (SCN) of hypothalamus.

Circadian rhythms, under artificially constant environmental condition, run with a period slightly different from $24 \mathrm{~h}$. However, under natural conditions, the $\mathrm{SCN}$ is reset every day by light-dark alternance through the retino-hypothalamic tract (RHT). ${ }^{5}$ Each of its neurons acts as an individual oscillator based on clock gene feedback loop, composed by positive (CLOCK and $B M A L 1)$ and negative limbs (PER and CRY). Although the photic input is the main SCN entraining signal, other periodical cues such as feeding time and scheduled exercise can also entrain the mammalian circadian system. ${ }^{67}$ Furthermore, outputs pathways are responsible for the coordination of circadian rhythm between different functions and most peripheral tissues and organs. These are the result of humoral mediators such as prokineticin-2, which is able to generate the rhythm of locomotor activity, ${ }^{8}$ and neural outputs, such as the rhythmic change in the parasympathetic/sympathetic balance, ${ }^{9}$ or the pineal release of melatonin during darkness. ${ }^{10}$

\section{The biological clock at a molecular level}

In its simplest form, circadian clocks are composed of a set of proteins that generate self-sustained circadian oscillations through positive and negative transcriptional/translational feedback loops. Although the whole picture of the clock model is continuously evolving, the positive limb of the molecular clock comprises two transcription factors, CLOCK and BMAL1, whereas PERs and CRYs are responsible for the negative limb. In addition to these core clock genes, other genes of SCN neurons, which are not components of the circadian mechanisms, but whose expression is regulated by clock genes, oscillate with a periodicity close to $24 \mathrm{~h}$. They are the so-called clock-controlled genes (CCG) or circadian output genes (fig. 1). ${ }^{11,12}$ These genes orchestrated by the SCN in due time, are necessary for creating and sustaining rhythms of $24 \mathrm{~h}$. In addition, posttransla- 


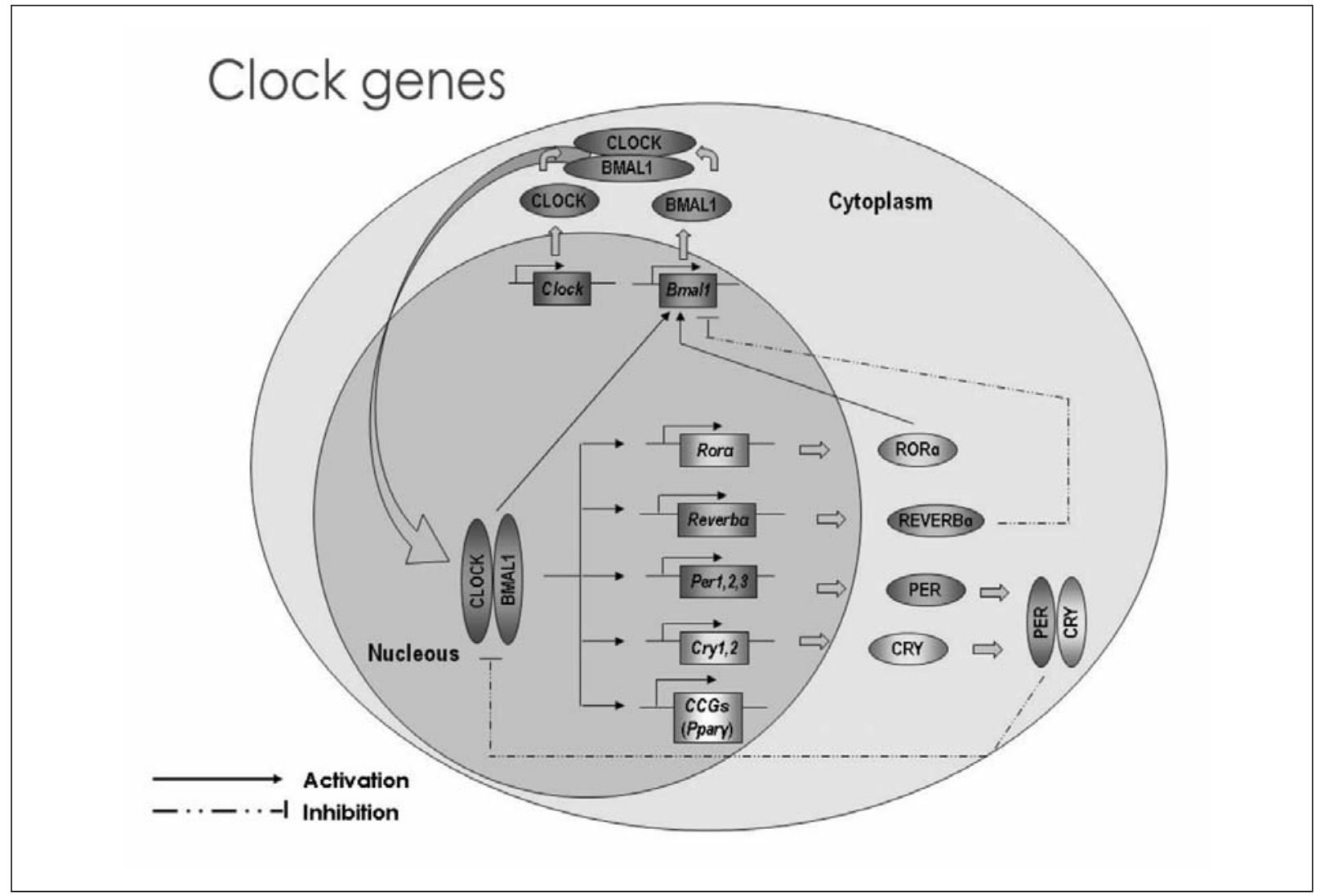

Fig. 1.-Molecular machinery of circadian clock. The core of the circadian clock is composed of two basic helix-loop-helix transcription factors, CLOCK and BMAL1, which act as positive limb in the feedback loop. The heterodimer CLOCK-BMAL1 binds in the promoter of some target genes, driving the transcription of several repressor encoding genes: three period genes (PER1, PER2 and PER3), two cryptocrome (CRY1 and CRY2) and the transcription factor REV-ERB $\alpha$ gene, and one promoting gene, ROR $\alpha$. In addition, the product of PPAR $\alpha$ gene, one of the clock controlled gene regulated by the circadian oscillator (CCG), induces BMAL1 and REV-ERB $\alpha$ transcription. PER and CRY proteins dimerize and are then translocated into the nucleus counteracting the positive effect of CLOCK-BMAL1 and thereby inhibit their own transcription. In addition, BMAL1 rhythm is also regulated by rhythmical changes in RORE occupancy by REV-ERB $\alpha$ (activating) and ROR $\alpha$ (inhibiting).

tional mechanisms such as protein phosphorylation, affect stabilization, degradation, and subcellular localization of clock proteins, thus contributing to the molecular clockwork. ${ }^{13,14}$ However, one of the most interesting outcomes in the chronobiological field has been the discovery of different peripheral clocks in many tissues and organs such as liver, oral mucosa, heart and kidneys among other. ${ }^{15}$

\section{Chronodisruption: causes and consequences}

Circadian disruption or Chronodisruption (CD) is defined as a relevant disturbance of the internal temporal order of physiological and behavioral circadian rhythms. It is also a breakdown of the normal phase relationship between the internal circadian rhythms and 24-h environmental cycles. In our modern society, $\mathrm{CD}$ may be common in several conditions such as jet lag, shift work, light at night, or social jet lag. ${ }^{16}$ In addition clock gene polymorphisms and aging may have also chronodisruptive effects.
Thus, CD can be induced by factors related to the following: 1) Impairment of the inputs to the circadian pacemaker: low contrast between day and night synchronizing agents (continuous light, frequent snacking, low levels of physical exercise, etc.); exposure to zeitgebers of different periods or unusual phasing (i.e., light at night, nocturnal feeding, nocturnal physical exercise) or by frequent shifts in the time provided by zeitgebers (i.e., jet lag, shift work). 2) Circadian oscillators: the uncoupling between different subpopulations of oscillators inside the SCN caused by aging or clock gene alterations and the uncoupling between central pacemaker and peripheral oscillators also result in chronodisruption. 3) Outputs: the suppression of nocturnal melatonin and the loss of cortisol rhythm are also chronodisrupters.

Clinical and epidemiological studies have shown that certain situations such as shift work, eat during night-time, exposure to bright light or sleep deprivation are contributing to $\mathrm{CD}$ and this situation is related to the increasing risk of developing certain diseases and with the impairment of preexisting pathologies such as 


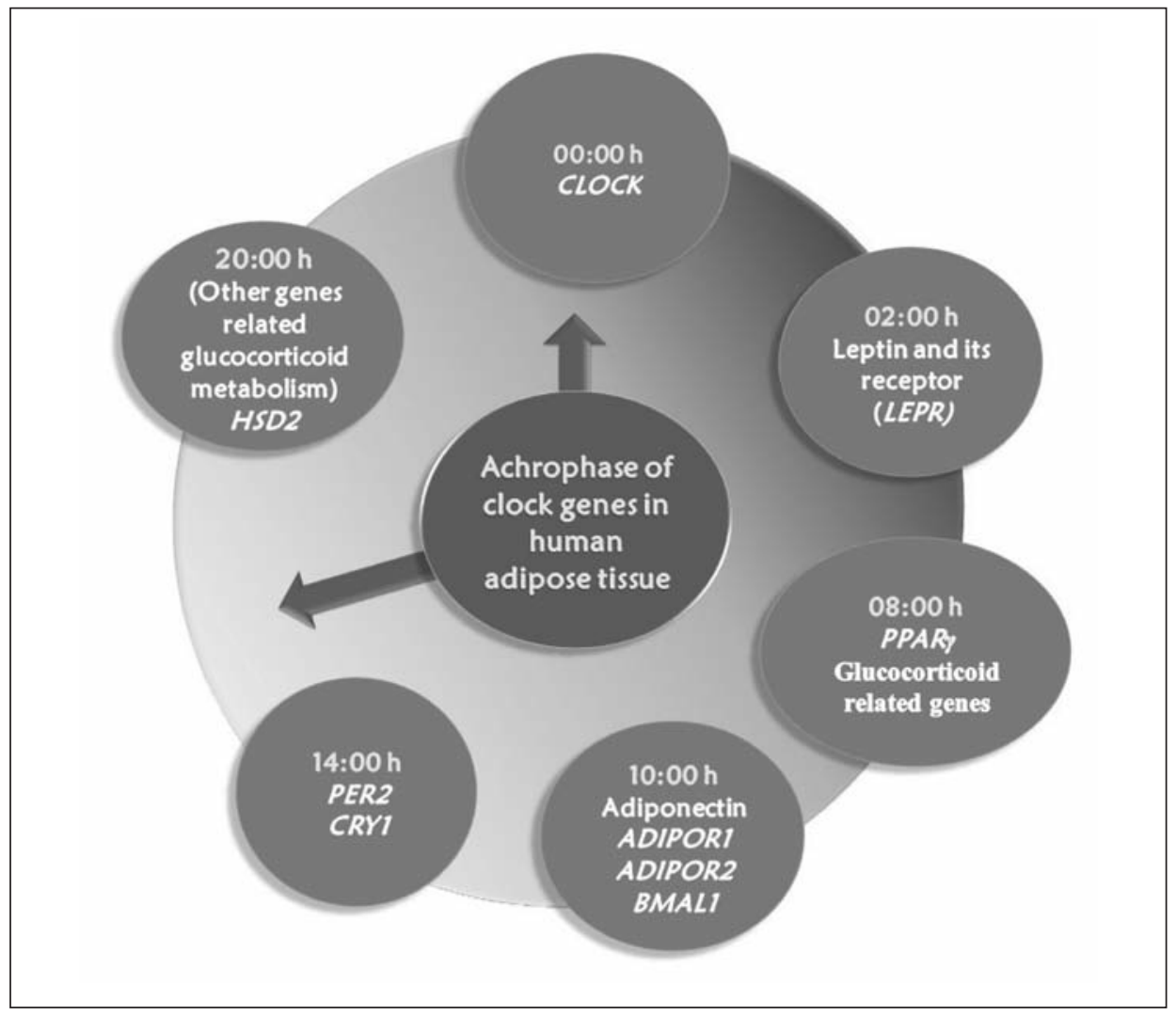

Fig. 2.-Rhythmic expression of genes studied: (leptin and its receptor (LEPR), adiponectin and its receptors (ADIPOR1 and ADIPOR2), clock genes (PER2, BMAL1, and CRY1) and glucocorticoid metabolism-related genes (PPARg, GR, HSD1, HSD2, and 5aR) in human subcutaneous and visceral adipose tissue. Adipose depots were isolated at 6-h intervals over the course of the day from adipose tissue cultures (time at 0, 6, 12, and $18 \mathrm{~h}$ ). Results are presented relative to the lowest basal relative expression for each gene. Data of relative expression are represented as arbitrary units $(A U)$. Data are reported as means.

such as cancer, obesity, metabolic syndrome, insomnia, cognitive and affective disorders and premature ageing.

Interesting results have arisen from studies relating sleep duration and metabolic risk. The time we sleep has declined by $1.5 \mathrm{~h}$ over the past century, accompanied by an important increase in obesity. Moreover, a third of adults sleep less than six hours a night. ${ }^{17}$ Different causes could explain the association between sleep loss and obesity. Studies with adults have shown associations between inadequate sleep and alterations in leptin and/or ghrelin indicative of increased appetite. ${ }^{18,19}$ Moreover, short sleep duration could lead to weight gain and obesity by increasing the time available to eat and has also been theorized to decrease energy expenditure by increased fatigue as well as changes in thermoregulation which could explain obesity.

\section{Adipose tissue changes during the day}

One of the most important questions related to the circadian system and obesity, was to elucidate if adipose tissue displayed circadian rhythmicity or whether it had an internal peripheral clock. Analysis of murine adipose tissue revealed robust $24 \mathrm{~h}$ rhythms of clock gene expression. The relative phasing of genes in adipose tissue is consistent with SCN rhythms and the molecular model of the circadian clock. ${ }^{20,21}$ Moreover, use of micro- arrays suggests that up of $20 \%$ of the murine and the human adipose transcriptome is expressed according to diurnal rhythm]. ${ }^{21,23}$

Therefore, a recent study performed by our group of research has provided an overall view of the internal temporal order of circadian rhythms in human adipose tissue represented in a phase map. ${ }^{24}$ The data included various genes implicated in metabolic processes such as energy intake and expenditure, insulin resistance, adipocyte differentiation, dyslipidemia, and body fat distribution, and indicated that circadian rhythmicity of the genes studied followed a predictable physiological pattern, particularly for subcutaneous depot. As expected, leptin, a peripherally synthesized hormone which acts as an anorexigenic hormone in the brain, showed its achrophase (maximum expression) during the night (at 02:00 hours). The expression of adiponectin (ADIPOQ) achieved its zenith (maximum) during the morning (at 10:00 hours) which could be implicated in the maximal withdrawal of fatty acids, and the improvement in glucose tolerance and that time. ${ }^{25} P P A R \gamma$ could be also related to $A D I P O Q$ circadian pattern. In fact, the high expression of PPAR $\gamma$ and glucocorticoides related genes during the morning (08:00 hours), located at the beginning of the of the daily activity, is consistent with results obtained in nocturnal mammals ${ }^{26}$ and could be influencing the further increase in $A D I P O Q$ expression and the increase in insulin sensitivity during this time of the day. Moreover, our investigation group has demon- 
strated that these clock also changes with different factors including sex, ${ }^{27}$ menopause, ${ }^{28}$ stress $^{29}$ and obesity. ${ }^{30,31}$

\section{The time is important}

\section{Time offood}

Many factors have been recognized to influence the success of a dietary intervention in obesity. ${ }^{32-41}$ Indeed, obesity is a heterogeneous condition and individual responses to standardized protocols targeting weight loss are highly variable. ${ }^{2}$ In real life settings such as obesity treatment programs, physiological and psychological factors, some of which may carry a strong genetic influence, interact with environmental factors in a complex manner..$^{3-5}$ Recent studies link energy regulation to the circadian clock at the behavioural, physiological, and molecular levels, ${ }^{6-9}$ emphasizing that the timing of food intake itself may play a significant role in weight regulation. ${ }^{10}$

In this regards, our group of investigation has performed the first prospective longitudinal study showing that timing of food intake relates with weigh loss effectiveness in humans. In 420 overweight/obese patients undergoing a 20 -week weight-loss diet, those who ate their main meal late (after 15:00 h) lost significantly less weight than early eaters (before 15:00 h). ${ }^{42}$ The current findings may help in the development of novel therapeutic strategies incorporating not only the caloric intake and macronutrient distribution —as is classically done- but also the timing of food.

\section{Chronobiology and Genetic aspects}

From the genetic epidemiology point of view, the study of single nucleotide polymorphisms (SNPs) is contributing to the identification of the genetic background of chronotypes (morningness or eveningness), sleep alterations, or seasonal mood disorders. All these advances have allowed researchers to find the relevant link which exists between chronobiology and obesity.

Genetic polymorphisms in human clock genes have been associated with increased incidence of obesity in epidemiological studies. Different authors are currently investigating the role of clock gene variants and their predicted haplotypes in human obesity and MetS alterations. ${ }^{43-45}$ From studies of our own group and others we deduce that CLOCK gene SNPs rs3749474, rs4580704 and rs1801260 $(3111 \mathrm{~T}>\mathrm{C})$ polymorphisms, are particularly interesting, since they seem to be associated with BMI, energy intake and different obesity-related variables. ${ }^{46,47}$ Moreover, different psychological traits have been related to $C L O C K 3111 \mathrm{~T}>\mathrm{C} \mathrm{SNP}{ }^{48,49}$ The association with psychological illnesses is related to the fact that minor allele carriers of CLOCK $3111 \mathrm{TC}$ display sleep disorders and eveningness,${ }^{34}$ characteristics that, in addition, make these subjects susceptible to obesity.
Moreover a recent study shows the association of the CLOCK 3111T/C SNP with obesity and weight loss. In this work, $\mathrm{C}$ genetic variants in CLOCK $3111 \mathrm{~T} / \mathrm{C}$ display a less robust circadian rhythm than TT and a delayed acrophase, which characterizes "evening-type" subjects..$^{50}$ We also found different effects across CLOCK $3111 \mathrm{~T} / \mathrm{C}$ genotypes for saturated fatty acid intake ( $\%$ of energy) and the deleterious effect of gene variants on waist circumference was only found with high saturated fatty

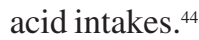

\section{Epigenetics, Chronobiology and Obesity}

Epigenetic research shows that we are not predetermined by our genome. What we eat, how much we sleep, if we exercise or even how we use our mind may change our epigenome, and our fate. Moreover, these changes are not restrained to us but can pass down to our children or even to our grant children. In other words, epigenetics does not change the DNA but decides how much or whether some genes are expressed in different cells in our bodies.

The molecular basis of epigenetics is complex. It involves modifications of the activation of certain genes, but not the core DNA structure. One way that gene expression is regulated is by the remodeling of chromatin (the complex of DNA and histones). Chromatin proteins associated with DNA may be activated or silenced. Histones can change how tightly or loosely the DNA wraps around them by modifying their amino acids. If the amino acids that are in the chain are changed, the shape of the histone sphere might be modified.

A second way of chromatin remodeling is the addition of methyl groups to the DNA, mostly at $\mathrm{CpG}$ sites, which are regions of DNA where a cytosine nucleotide occurs next to a guanine nucleotide. " $\mathrm{CpG}$ " is shorthand for "- $\mathrm{C}-$ phosphate- $-\mathrm{G}-$ ", that is, cytosine and guanine separated by only one phosphate. Methylation converts cytosine to 5-methylcytosine. Some areas of the genome are methylated more heavily than others, and highly methylated areas tend to be less transcriptionally active.

In 2011, it was demonstrated for the first time that the methylation of mRNA had a critical role in human energy homeostasis. Obesity associated FTO gene was shown to be able to demethylate N6-methyladenosine in RNA. This opened the related field of RNA epigenetics and its relation to obesity.

Despite this conceptual knowledge, data about the connection between this circadian epigenome and obesity are still scarce. Nevertheless, recently our group has demonstrated an association between the methylation status of $\mathrm{CpG}$ sites located in clock genes (CLOCK, $B M A L 1$ and PER2) with obesity, Metabolic Syndrome and weight loss. ${ }^{31}$ Our research unveils new epigenetic mechanisms involving clock genes that may contribute to better obesity prevention, as well as better prediction of successful weight reduction. Of note, these new data 


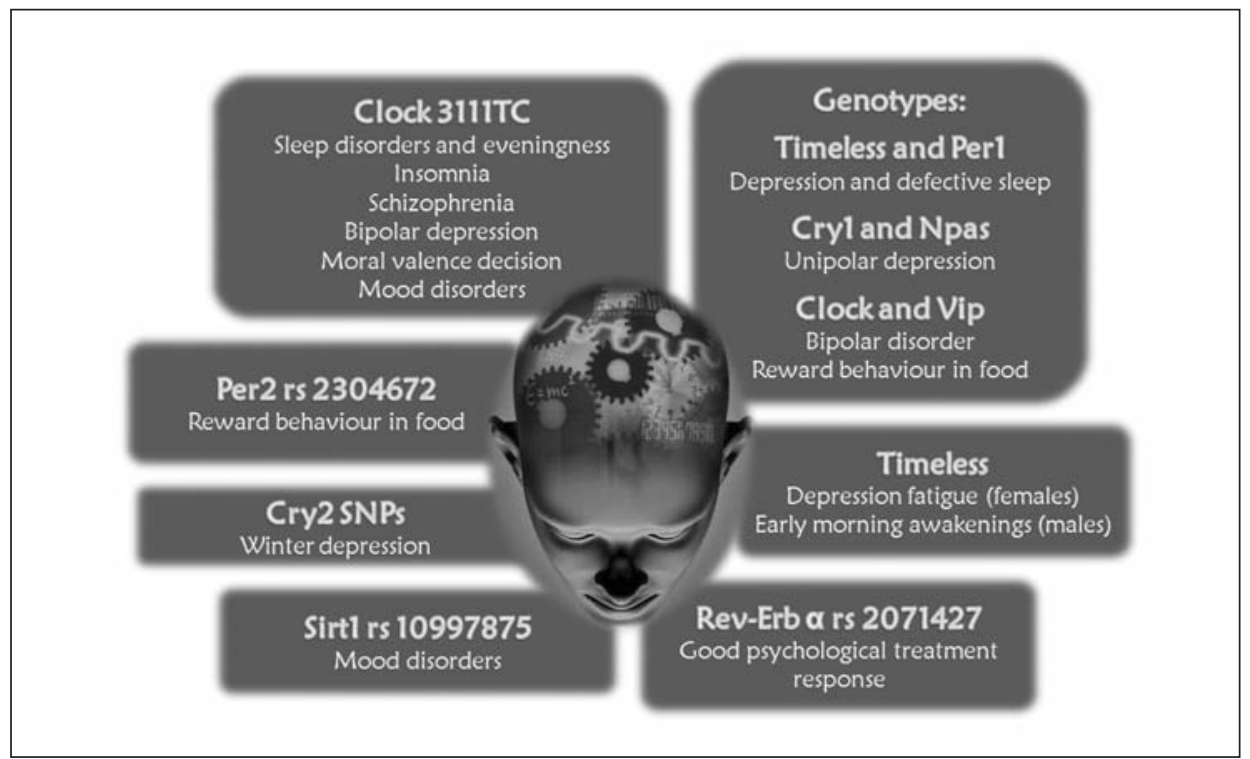

Fig. 3.-Main genetic variants related to psychological traits.

related to DNA methylation are consistent with previous results related to $C L O C K$ genetic variants, which demonstrated that sleep reduction, changes in ghrelin values, alterations of eating behaviors and evening preference are all connecting genetics, chronodisruption and obesity. ${ }^{34}$ These results support the hypothesis that the influence of the clock genes may be extended to a broad range of variables linked with human behavior and metabolism. Moreover, our data pave the way to the study of epigenetic mechanisms in the regulation of circadian rhythms in relation to obesity and weight loss.

\section{Genetic, Chronotype, and Psychological Traits: Towards a deepest approach on their connections}

Initially, the emphasis of chronobiology genetics was placed on the study of the association between chronotype and different psychological illnesses such as depression, anxiety, or bipolar disorder. Other mood features that have been associated with clock genes are stress, seasonality, and personality traits related to the chronotype such as the morningness/eveningness profile.

Taking into account that obesity is related to behavior and also with personality traits, and considering that the chronotype is behind some of these relationships, an obvious step was to link these psychologicalrelated SNPs with obesity-related traits. Proof of this hypothesis is the case of CLOCK and PER2 SNPs that were firstly associated with mood disorders and then to obesity and Metabolic Syndrome (MetS) (fig. 3).

\section{Conclusion}

The study of circadian rhythms of the individual is of great use in medicine today. The development of this new science is being vertiginous and its applications in the prevention of certain diseases such as cancer or obesity could be innumerable. Still further studies are needed to reach decisive conclusions.

\section{References}

1. Halket AC. The Flowers of Silene Saxifraga, L.; an Inquiry into the Cause of their Day Closure and the Mechanism concerned in Effecting their Periodic Movements. Annals of Botany 1931; $1: 15$.

2. la Fleur SE, Kalsbeek A, Wortel $\mathrm{J}$ et al. A daily rhythm in glucose tolerance: a role for the suprachiasmatic nucleus. Diabetes 2001; 50: 1237-43.

3. Bozek K, Relógio A, Kielbasa SM, Heine M, Dame C, Kramer A et al. Regulation of clock-controlled genes in mammals. PLoS One 2009; 4 (3): e4882.

4. Aschoff J. Circadian rhythms: general features and endocrinological aspects. En: Endocrine Rhythms. Krieger DT, ed. New York: Raven Press, 1979; p. 1-61.

5. Moore RY, Speh JC, Leak RK. Suprachiasmatic nucleus organization. Cell Tissue Res 2002; 309: 89-98.

6. Lax P, Zamora S, Madrid JA. Coupling effect of locomotor activity on the rat's circadian system. Am J Physiol 1998; 275: R580-7.

7. Lax P, Zamora S, Madrid JA. Food-entrained feeding and locomotor circadian rhythms in rats under different lighting conditions. Chronobiol Int 1999; 16: 281-91.

8. Zhou QY, Cheng MY. Prokineticin 2 and circadian clock output. FEBS J 2005; 272 (22): 5703-9.

9. Buijs RM, la Fleur SE, Wortel J, Van Heyningen C, Zuiddam L, Mettenleiter TC et al. The suprachiasmatic nucleus balances sympathetic and parasympathetic output to peripheral organs through separate preautonomic neurons. J Comp Neurol 2003; 464 (1): 36-48.

10. Moore RY. Neural control of the pineal gland, Behav. Brain Res 1996; 73 (1-2): 125-30.

11. Froy O. The relationship between nutrition and circadian rhythms in mammals. Front Neuroendocrinol 2007; 28: 61-71.

12. Laposky AD, Bass J, Kohsaka A, Turek FW. Sleep and circadian rhythms: key components in the regulation of energy metabolism. FEBS Lett 2008; 582: 142-51.

13. Lee C, Etchegaray JP, Cagampang FR, Loudon AS, Reppert SM. Posttranslational mechanisms regulate the mammalian circadian clock. Cell 2001; 107 (7): 855-67. 
14. Pevet P, Challet E. Melatonin: both master clock output and internal time-giver in the circadian clocks network. J Physiol Paris 2011; 105(4-6): 170-82.

15. Balsalobre A, Damiola F, Schibler U. A serum shock induces circadian gene expression in mammalian tissue culture cells. Cell 1998 Jun 12; 93 (6): 929-37.

16. Garaulet M, Ordovás JM, Madrid JA. The chronobiology, etiology and pathophysiology of obesity. Int J Obes (Lond) 2010 Dec; 34 (12): 1667-83

17. Bonnet MH, Arand DL. We are chronically sleep deprived. Sleep 1995; 18: 908-11.

18. Taheri S, Lin L, Austin D, Young T, Mignot E. Short sleep duration is associated with reduced leptin, elevated ghrelin, and increased body mass index. PLoS Med 2004 Dec; 1 (3): e62.

19. Chaput JP, Despres JP, Bouchard C, Tremblay A. Short sleep duration is associated with reduced leptin levels and increased adiposity: results from the Quebec family study. Obesity (Silver Spring) 2007 Jan;15 (1): 253-61.

20. Ando H, Yanagihara H, Hayashi Y, Obi Y, Tsuruoka S, Takamura $\mathrm{T}$ et al. Rhythmic mRNA Expression of Clock Genes and Adipocytokines in Mouse Visceral Adipose Tissue. Endocrinology 2005; 146 (12): 5631-6.

21. Zvonic S, Ptitsyn AA, Conrad SA, Scott LK, Floyd ZE, Kilroy G et al. Characterization of peripheral circadian clocks in adipose tissues. Diabetes 2006; 55 (4): 962-70.

22. Ptitsyn AA, Zvonic S, Conrad SA, Scott LK, Mynatt RL, Gimble JM. Circadian clocks are resounding in peripheral tissues. PLoS Comput Biol 2006; 2 (3): e16.

23. Loboda A, Kraft WK, Fine B, Joseph J, Nebozhyn M, Zhang C et al. Diurnal variation of the human adipose transcriptome and the link to metabolic disease. BMC Med Genomics 2009; 2: 7.

24. Garaulet M, Ordovás JM, Gómez-Abellán P, Martínez JA, Madrid JA. An approximation to the temporal order in endogenous circadian rhythms of genes implicated in human adipose tissue metabolism. J Cell Physiol 2011; 226 (8): 2075-80.

25. Gómez-Abellán P, Gómez-Santos C, Madrid JA, Milagro FI, Campion J, Martínez JA et al. Circadian expression of adiponectin and its receptors in human adipose tissue. Endocrinology 2010; 151 (1): 115-22

26. Yang X, Downes M, Yu RT, Bookout AL, He W, Straume M et al. Nuclear receptor expression links the circadian clock to metabolism. Cell 2006; 126 (4): 801-10.

27. Gómez-Abellán P, Madrid JA, Luján JA, Frutos MD, González R, Martínez-Augustín O et al. Sexual dimorphism in clock genes expression in human adipose tissue. Obes Surg 2012 Jan; 22 (1): 105-12.

28. Hernández-Morante JJ, Gómez-Santos C, Margareto J, Formiguera X, Martínez CM, González R et al. Influence of menopause on adipose tissue clock gene genotype and its relationship with metabolic syndrome in morbidly obese women. Age (Dordr) 2012; 34 (6): 1369-80.

29. Gómez-Abellán P, Díez-Noguera A, Madrid JA, Luján JA, Ordovás JM, Garaulet M. Glucocorticoids affect 24 h clock genes expression in human adipose tissue explant cultures. PLoS One 2012; 7 (12): e50435.

30. Corbalán-Tutau MD, Madrid JA, Ordovás JM, Smith CE, Nicolás F, Garaulet M. Differences in daily rhythms of wrist temperature between obese and normal-weight women: associations with metabolic syndrome features. Chronobiol Int 2011; 28 (5): 425-33.

31. Milagro FI, Gómez-Abellán P, Campión J, Martínez JA, Ordovás JM, Garaulet M. CLOCK, PER2 and BMAL1 DNA Methylation: Association with Obesity and Metabolic Syndrome Characteristics and Monounsaturated Fat Intake. Chronobiol Int 2012 Nov; 29 (9): 1180-94

32. Corbalán MD, Morales EM, Canteras M, Espallardo A, Hernández T, Garaulet M. Effectiveness of cognitive-behavioral therapy based on the Mediterranean diet for the treatment of obesity. Nutrition 2009 Jul-Aug; 25 (7-8): 861-9.
33. Teixeira PJ, Silva MN, Coutinho SR, Palmeira AL, Mata J, Vieira PN et al. Mediators of weight loss and weight loss maintenance in middle-aged women. Obesity (Silver Spring) 2010; 18 (4): 725-35.

34. Garaulet M, Sánchez-Moreno C, Smith CE, Lee YC, Nicolás F, Ordovás JM. Ghrelin, sleep reduction and evening preference: relationships to CLOCK $3111 \mathrm{~T} / \mathrm{C} \mathrm{SNP}$ and weight loss. PLoS One 2011; 6 (2): e17435.

35. Garaulet M, Esteban Tardido A, Lee YC, Smith CE, Parnell LD, Ordovás JM. SIRT1 and CLOCK $3111 \mathrm{~T}>\mathrm{C}$ combined genotype is associated with evening preference and weight loss resistance in a behavioral therapy treatment for obesity. Int $J$ Obes (Lond) 2012; 36 (11): 1436-41.

36. Garaulet M, Corbalán-Tutau MD, Madrid JA, Baraza JC, Parnell LD, Lee YC et al. PERIOD2 variants are associated with abdominal obesity, psycho-behavioral factors, and attrition in the dietary treatment of obesity. J Am Diet Assoc 2010; 110 (6): 917-21.

37. Oishi K, Shirai H, Ishida N. CLOCK is involved in the circadian transactivation of peroxisome-proliferator-activated receptor alpha (PPARalpha) in mice. Biochem J 2005; 386: 575-81.

38. Turek FW, Joshu C, Kohsaka A, Lin E, Ivanova G, McDearmon E et al. Obesity and metabolic syndrome in circadian Clock mutant mice. Science 2005; 308: 1043-5

39. Marcheva B, Ramsey KM, Buhr ED, Kobayashi Y, Su H, Ko $\mathrm{CH}$ et al. Disruption of the clock components CLOCK and BMAL1 leads to hypoinsulinaemia and diabetes. Nature 2010; 466: 627-31.

40. Froy O. Metabolism and circadian rhythms-implications for obesity. Endocr Rev 2010; 31: 1-24

41. Arble DM, Bass J, Laposky AD, Vitaterna MH, Turek FW. Circadian timing of food intake contributes to weight gain. Obesity (Silver Spring) 2009; 17: 2100-2.

42. Garaulet M, Gómez-Abellán P, Alburquerque-Béjar JJ, Lee YC, Ordovás JM, Scheer FA. Timing of food intake predicts weight loss effectiveness. Int J Obes (Lond) 2013 Jan; 29.

43. Rechtschaffen A, Bergmann BM. Sleep deprivation in the rat by the disk-over-water method. Behav Brain Res 1995; 69: 5563.

44. Garaulet M, Lee YC, Shen J, Parnell LD, Arnett DK, Tsai MY et al. CLOCK Genetic Variation and Metabolic Syndrome Risk: Modulation by Monounsaturated Fatty Acids. Am J Clin Nutr 2009 Dec; 90 (6): 1466-75.

45. Sookoian S, Gemma C, Gianotti TF, Burgueño A, Castaño G, Pirola CJ. Genetic variants of Clock transcription factor are associated with individual susceptibility to obesity. Am J Clin Nutr 2008; 87: 1606-15.

46. Garaulet M, Lee YC, Shen J, Parnell LD, Arnett DK, Tsai MY et al. Genetic variants in human CLOCK associate with total energy intake and cytokine sleep factors. Eur J Hum Genet 2010 Mar; 18 (3): 364-9.

47. Garaulet M, Corbalán MD, Madrid JA, Morales E, Baraza JC, Lee YC et al. CLOCK gene is implicated in weight reduction in obese patients participating in a dietary programme based in Mediterranean Diet. Int J Obes (Lond) 2010; 34 (3): 516-23.

48. Xu X, Breen G, Chen CK, Huang YS, Wu YY, Asherson P. Association study between a polymorphism at the $3 \phi$-untranslated region of CLOCK gene and attention deficit hyperactivity disorder. Behav Brain Funct 2010; 6: 48.

49. Serretti A, Benedetti F, Mandelli L, Lorenzi C, Pirovano A, Colombo $\mathrm{C}$ et al. Genetic dissection of psychopathological symptoms insomnia in mood disorders and CLOCK gene polymorphism. Am J Med Genet B Neuropsychiatr Genet 2003; 121B (1): 35-8

50. Bandín C, Martínez-Nicolás A, Ordovás JM, Ros Lucas JA, Castell P, Silvente T et al. Differences in circadian rhythmicity in CLOCK 3111T/C genetic variants in moderate obese women as assessed by thermometry, actimetry and body position. Int $J$ Obes (Lond) 2012 Nov; 27. 